\title{
12. DISCUSSION AND INTERPRETATION OF SOME PHYSICAL PROPERTIES
}

\author{
R. B. Whitmarsh, National Institute of Oceanography, England
}

A variety of interesting features in the physical properties was encountered when it was attempted to find some order among the apparently complex variations of physical parameters measured on board Glomar Challenger. These features are discussed briefly below mainly in the hope that they may stimulate further investigation; since this is a preliminary report many of the conclusions in this chapter should be treated as tentative.

\section{THE RELATIONSHIP BETWEEN NATURAL GAMMA ACTIVITY, CARBONATE CONTENT AND OTHER PARAMETERS}

It has been occasionally demonstrated and sometimes implicitly assumed in the descriptions of physical properties by site (Chapters 3 to 10) that an inverse relationship exists between natural gamma activity and carbonate content of the cores. In particular, detailed carbonate measurements by Honjo (Woods Hole Oceanographic Institution) using Hülsemann's (1966) method appear to substantiate this relationship (Figure 1). To investigate the generality of this relationship the carbonate determinations of each site were plotted against the gamma counts (adjusted to a sediment porosity of 60 per cent, as explained in Chapter 2) determined for the same intervals of core. These plots appear in Figure 2; data from adjacent sites have been pooled on the same plot.

The points in Figure 2a show good evidence of an inverse relationship. The line drawn by eye on the plot was constrained to pass through the point, (100 per cent carbonate, zero counts) and represents the trend of the data. The scatter of the points is probably due to several factors. First, the carbonate content may not be representative of the whole length of core (about 10 centimeters) which contributed to the gamma count; this is especially true when there are sharp lithological boundaries in the core. Second, the radioactivity per unit mass of the noncarbonate fraction is not necessarily constant. Other effects such as misalignment of the carbonate and gamma measurements (due to the core sliding in the liner between measurements) and erroneous porosity corrections (due to cores containing voids) have hopefully been eliminated in choosing the plotted data. The above remarks apply to the data of all sites.

Lines have been drawn on Figures $2 b$ and $2 c$ on the same basis as for Figure 2a, however, on these figures there are points falling well below the drawn lines. The explanation seems to be that the cores from which these points originate contain variable quantities of organic silica (Radiolaria, diatoms, sponge spicules), and such silica has no radioactivity. Thus, this silica combines with the carbonate in diluting the radioactivity of these cores. Points from possibly silica-rich samples are circled on the figures.

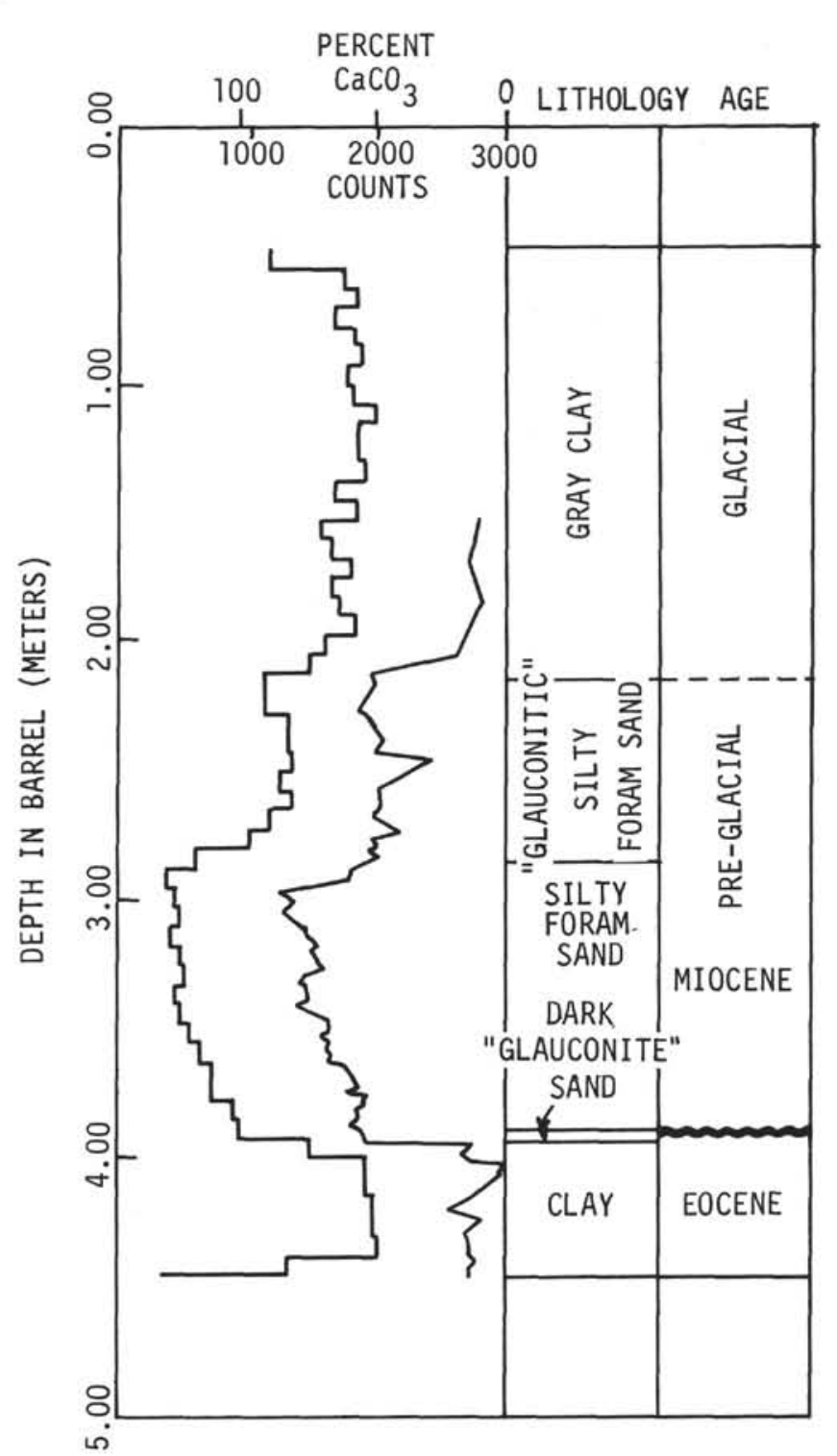

Figure 1. Comparison of detailed carbonate measurements, made by Honjo of Woods Hole Oceanographic Institution, and counts from natural gamma radioactivity along Core 111A-6. The curves illustrate the inverse relation between carbonate content and counts.

At Site 114, siliceous material was found in all the cores and it is believed that all the points in Figure $2 \mathrm{~d}$ are low due to this factor. A mean line from Figures $2 b$ and $2 c$ is drawn on this figure for comparison.

Data from Sites 116 and 117 are combined in Figure 2e. Here it seemed unreasonable to constrain the fitted line to have an intercept at 100 per cent carbonate and the data 


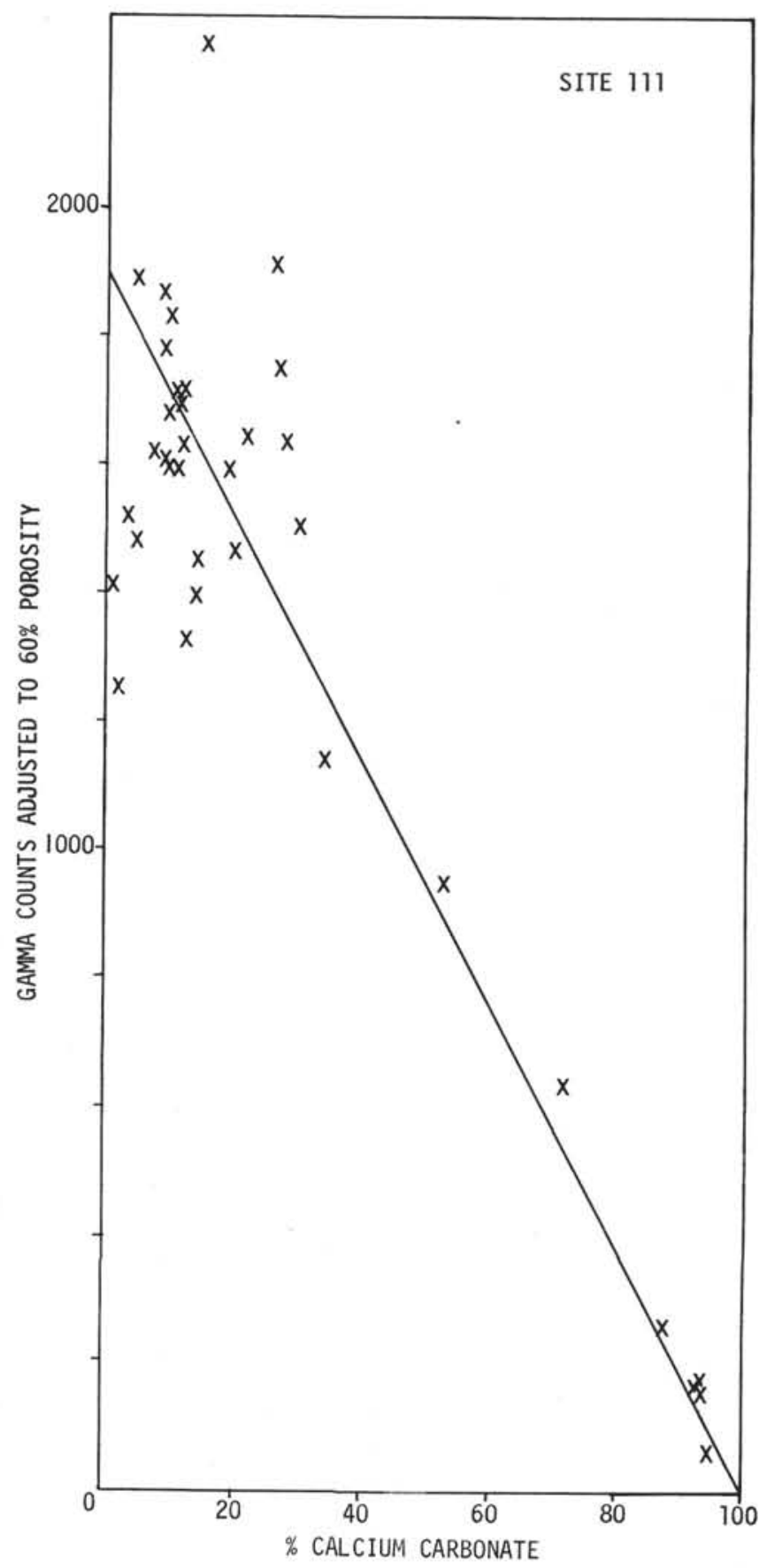

Figure 2a. See Figure $2 f$ for caption.

suggest that some of the carbonate at Site 116 may be slightly radioactive. However among marine carbonates only oolites and corals are known to absorb appreciable quantities of uranium yet the predominant lithology at Site 116 is foraminiferal-nannofossil ooze. The explanation may lie however in the considerable amount of authigenic carbonate found at the site in contrast to the normal situation where all the carbonate is due to the presence of microfossils. Alternately the widespread occurrence of pyrite at Site 116 suggests that these sediments were deposited under reducing conditions which favor enrichment in uranium (for example Turekian and Bertine, 1971).

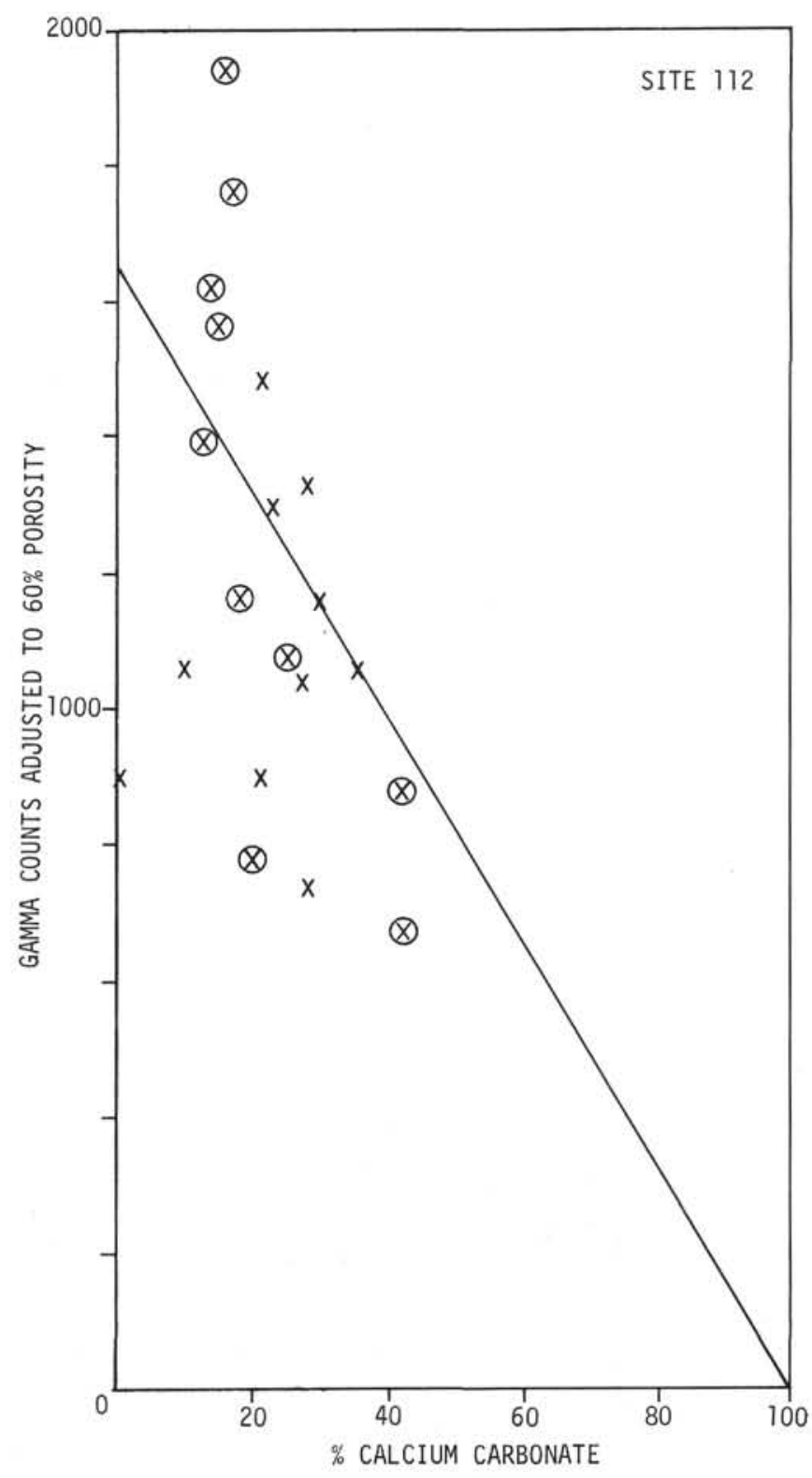

Figure 2b. See Figure $2 f$ for caption.

The anomalously low position of all four points from Hole $117 \mathrm{~A}$ is puzzling and, according to the lithological descriptions available, cannot be explained by a high content of organic silica.

Data from Sites 118 and 119 are combined on Figure $2 \mathrm{f}$ and show a well-defined inverse relation between carbonate content and gamma activity.

In conclusion, therefore, it is established that generally an inverse relation exists between carbonate content and gamma counts but when organic silica becomes an important constituent of a sediment it must also be included in the relation because of its diluting effect on radioactivity. On a carbonate-free basis the average gamma counts for each site lie between 1500 and 2300 corresponding to 3750 and 5750 counts, respectively, for a zero porosity carbonate-free sediment. 


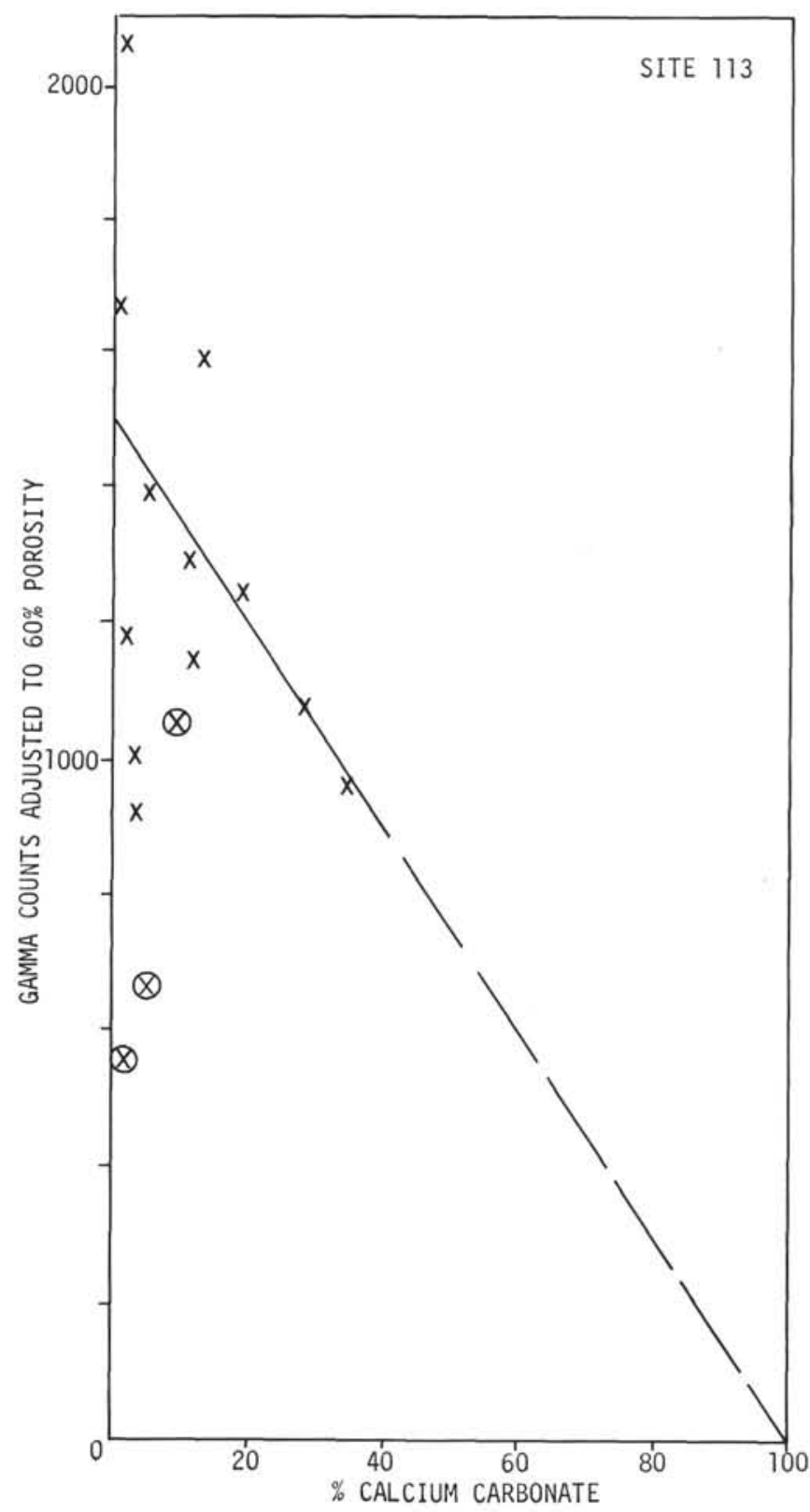

Figure 2c. See Figure $2 f$ for caption.

It was also often demonstrated in Chapters 3 to 10 that darker rocks have a greater natural gamma activity and vice versa. According to Barsukov et al. (1965), this relationship is due to the ease with which organic colloids absorb uranium and thorium ions and to the fact that darker rocks are associated with an increased amount of organic matter as well as the fact that dark rocks indicate anaerobic conditions which favour the precipitation of insoluble uranium and the preservation of organic remains. Beers (1945) and Russell (1945) found a similar positive correlation between organic carbon content and radioactivity. Hence a relationship may be expected between the amount of organic carbon and the gamma counts adjusted to a carbonate-free basis. These data are plotted by site in Figure 3. Only the mean counts for each 0.1 per cent step

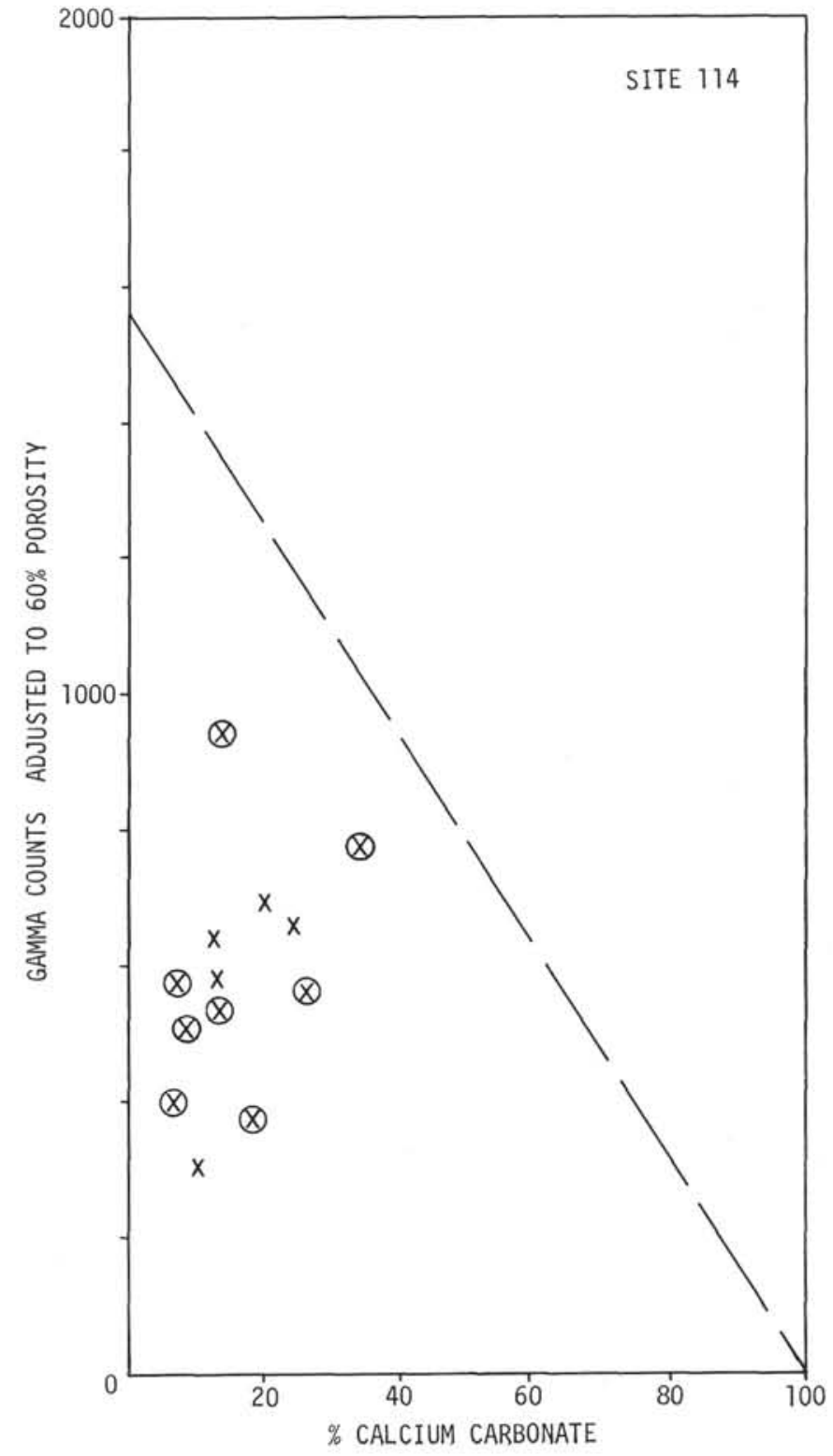

Figure 2d. See Figure $2 f$ for caption.

in organic carbon content are plotted because the gamma data show a wide scatter. Part of the scatter may also be due to the proportionally large uncertainty of \pm 0.06 per cent carbon in the organic carbon determination. The range of organic carbon values is limited in nearly every case, but the expected positive correlation exists only at Sites 112 and 113 . The reason for the gamma counts from sediment containing very little carbon exceeding those of cores with slightly more carbon may be as follows: The conditions under which organic carbon is normally added to sediments probably differ from those of detrital minerals (although some organic carbon may also be transported with the detrital minerals) which also contribute to the radioactivity of a sediment. Hence, a sediment practically free of organic carbon may yet contain appreciable quantities of detrital minerals so that an increase in gamma counts is observed. It was suggested in the descriptions of Sites 113,118 and 119 that the presence of mica might have increased the gamma 


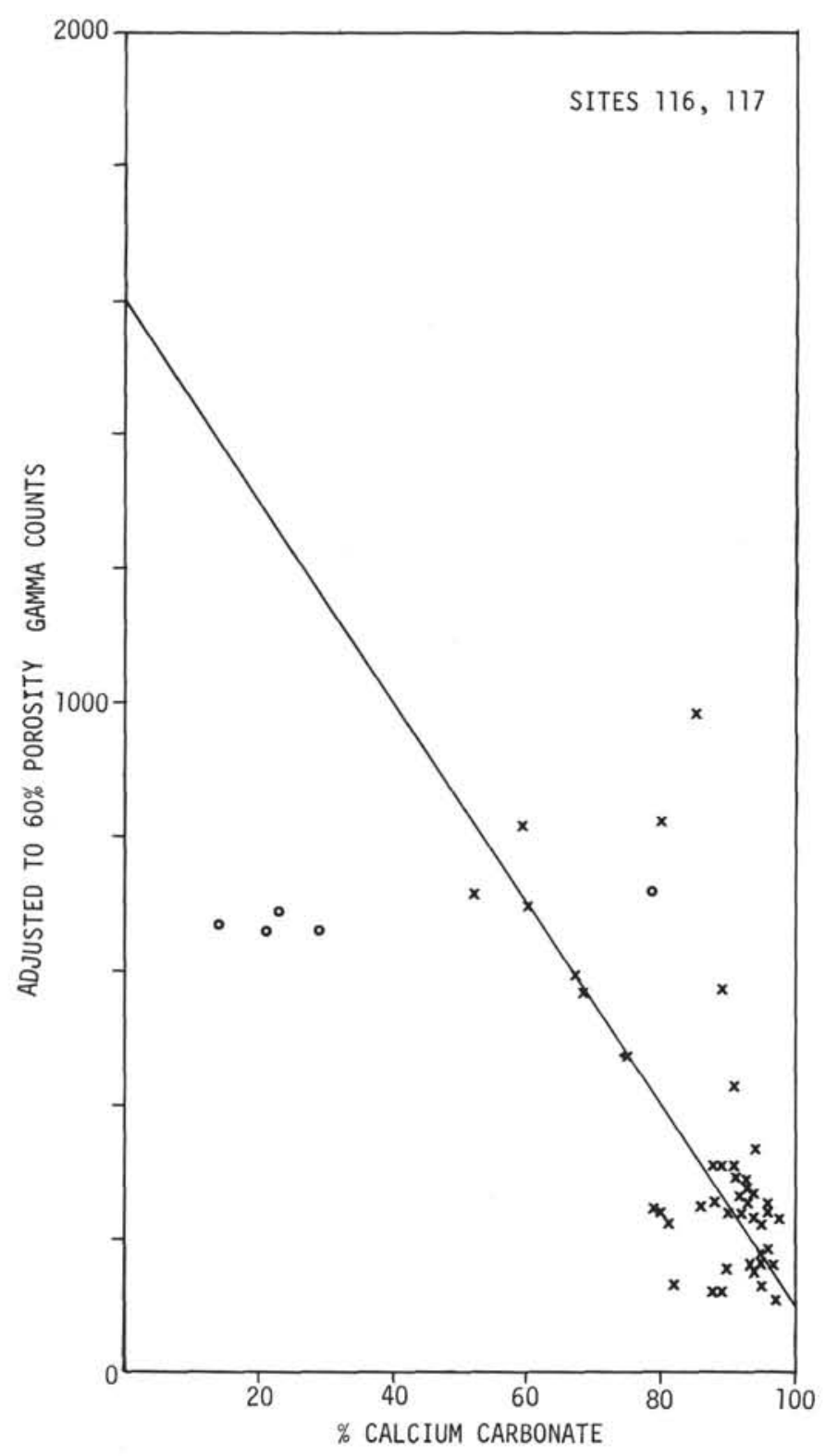

Figure 2e. See Figure $2 f$ for caption.

counts because not only do biotite and muscovite contain potassium but biotite may also have inclusions of radioactive monazite and zircon. Mica has been measured semiquantitatively (that is, on the basis that the sediments are composed of just a small number of minerals whose proportions are adjusted to constitute 100 per cent of the rock) by X-ray diffraction (see Appendices of Chapters 3 through 10). The gamma counts, adjusted to 60 per cent porosity, which were obtained closest to each single X-ray sample (many samples from one core were lumped together in the analyses; these results are excluded here) were plotted against the percentage of mica determined by X-ray analysis. Care was needed in looking for a relation between mica content and gamma counts since for some cores at least 70 per cent consisted of mica and calcite. Hence the percentage of mica represented a good estimate of the noncarbonate fraction which, as has been established

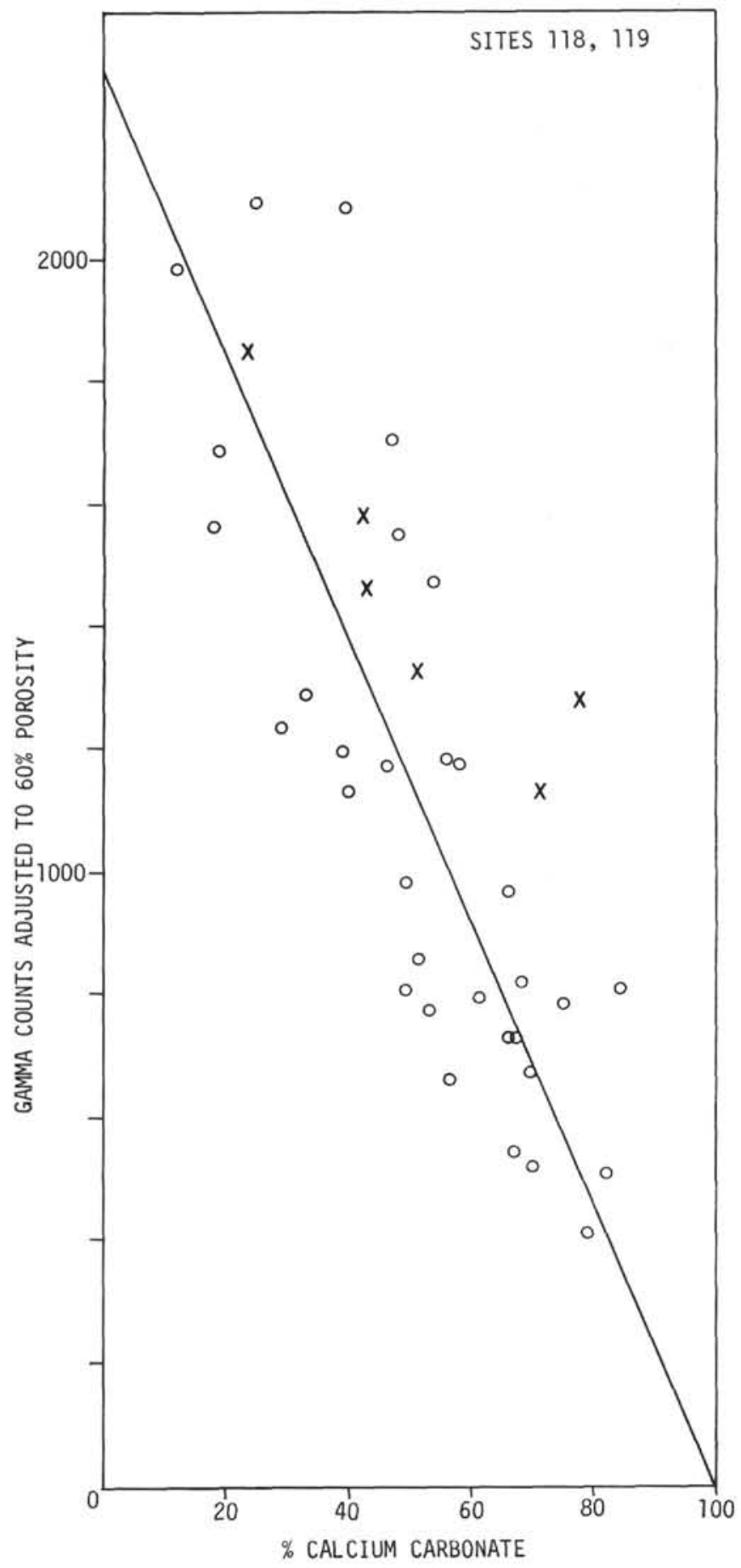

Figure 2f. Plots of natural gamma counts, adjusted to a porosity of $60 \%$ as explained in Chapter 2, against the weight percentage of calcium carbonate; circled symbols denote data from cores in which appreciable quantities of organic silica have been reported. In Figures $2 e$ and $2 f$ points from Sites 117 and 119 , respectively, are distinguished by open circles.

already, directly influences the gamma counts. Therefore, data were only included where the mica represented less than half of the noncarbonate fraction according to the $\mathrm{X}$-ray results. The remainder of this fraction consisted 


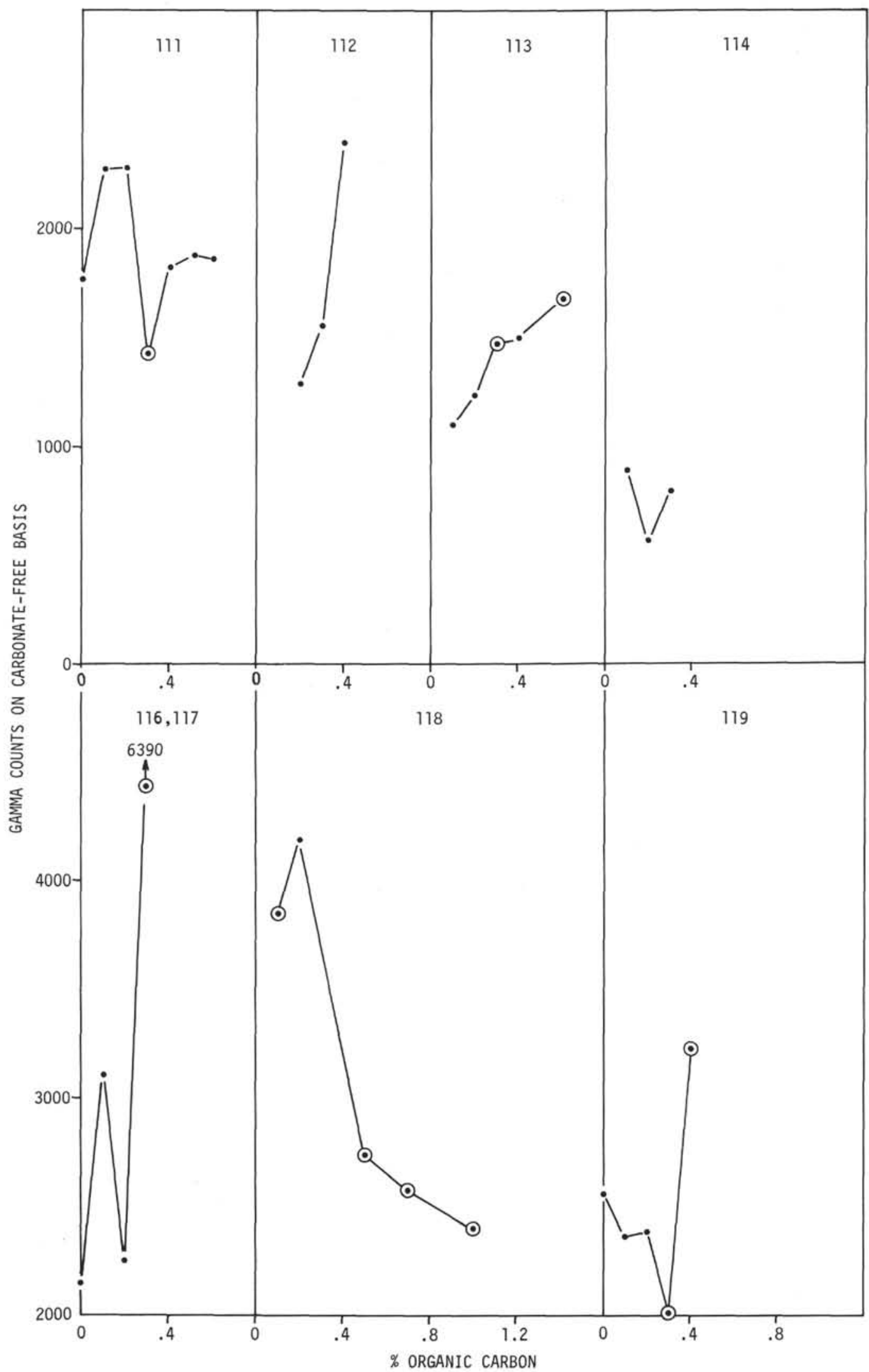

Figure 3. Plots of mean natural gamma counts, calculated on a carbonate-free basis, against the weight percentage of organic carbon. Circled points are based on just one carbonate sample. 
mainly of quartz, cristobalite, pyroxene and clay minerals. When no mica was detected, a point was plotted only if the carbonate content was less than 90 per cent.

The resulting mica/gamma counts plot is given in Figure 4. It is apparent that gamma counts are dependent on the proportion of mica almost to the extent that doubling the amount of mica will double the gamma counts since the fitted line passes very close to the origin. This is a remarkable result in that it appears that practically all the gamma activity in Leg 12 cores is attributable to detrital mica. However it must be remembered that the mica percentages are semiquantitative, that some effect due to the dependence of gamma counts on the size of the noncarbonate fraction may remain in the data, and that the majority of points in Figure 4 are derived from only two sites (111 and 112).

A further interesting aspect of the gamma data is the variation of gamma counts, calculated on a carbonate-free basis, with depth down each hole. Hopefully such a gamma/depth plot might show up variations in the proportion of detrital minerals as well as gross changes in sedimentation rate which should affect the degree of absorption by clays of uranium, thorium and potassium from sea-water. Plots of natural gamma counts against depth are shown in Figure 5.

For the data of Site 111 (Figure 5a) there is a slight suggestion of a two-fold division with a boundary at the depth of the top unconformity found at this site. An explanation of the decreasing count upwards across the boundary might be that as Orphan Knoll sank it became more cut off from a source of detrital minerals; alternatively the increasing sedimentation rate (1.0 to 2.5 $\mathrm{cm} / 10^{3} \mathrm{yr}$ ) may have had the same effect. The low counts seen at Site 113 (Figure 5c) between 200 and 260 meters are probably due to the preponderance of organic silica in these samples. The high counts between 550 and 720 meters at this site reflect the generally dark color of the sediments cored in this interval. As expected from Figure 2d, the counts for Site 114 (Figure 5d) are generally low and, in addition, there is no appreciable variation with depth. For Site 116, due to the non-zero count at 100 per cent carbonate, values calculated on a carbonate-free basis from carbonate contents close to 100 per cent will be anomalously high. Therefore all data based on carbonate contents in excess of 90 per cent have been omitted from the plot (Figure 5e). The data of Site 117 (Figure 5f) show the same group of four low counts as observed above. Site 118 (Figure 5g) shows no appreciable variation of counts with depth, nor does Site 119 (Figure 5h) except for a suggestion of a minimum around 360 meters. It may only be a coincidence that this is approximately the same depth at which there was a 9 million year break in sedimentation. In conclusion, the plots of carbonate-free counts against depth mainly seem to exhibit values scattered about a single mean, which is different for each site, except where there are appreciable changes in the proportion of nonradioactive organic silica in the cores. The best estimate of carbonatefree and silica-free counts for each site, derived from Figure 5 , are given in Table 1.

In spite of the allowances made to eliminate the effects of porosity, carbonate content and silica content from the

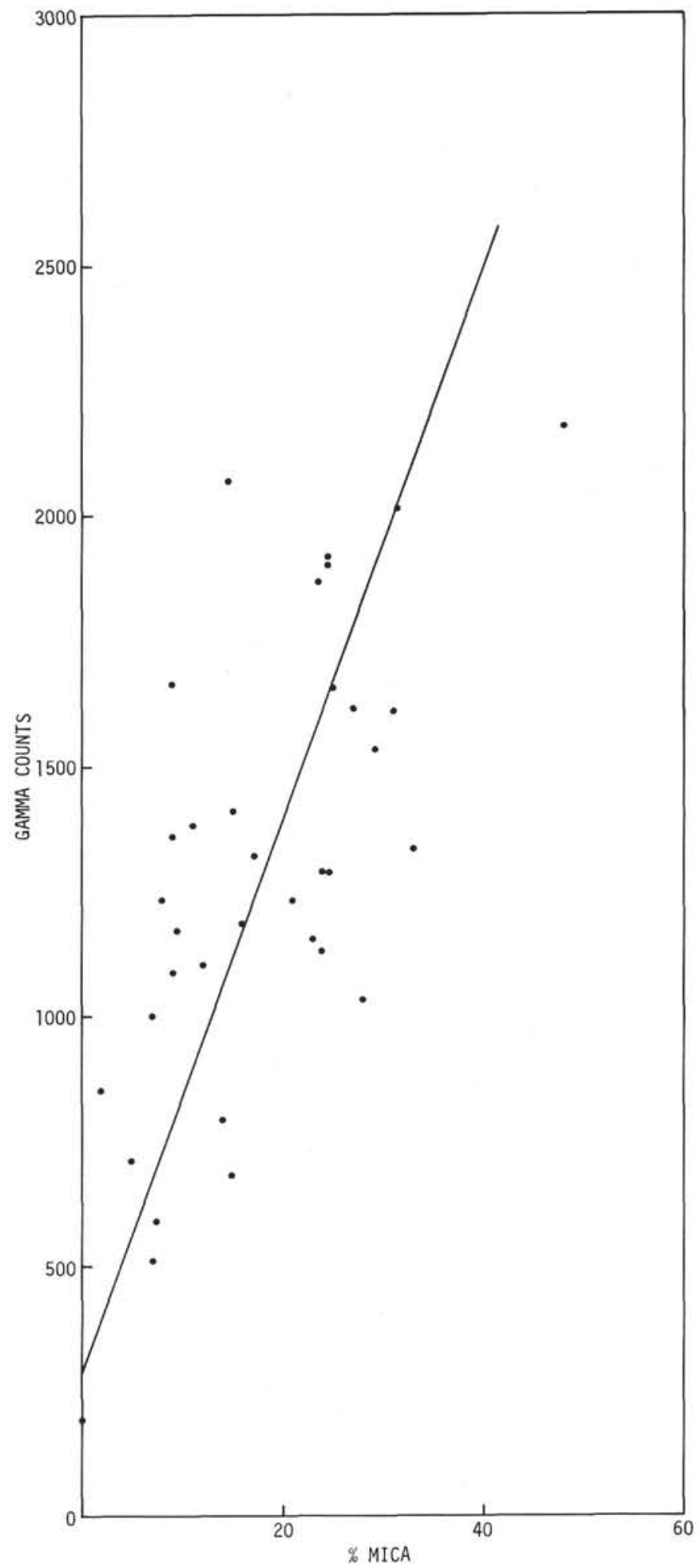

Figure 4. Percentage of mica determined by $X$-ray analysis plotted against gamma counts adjusted to $60 \%$ porosity (see text concerning choice of data points). The line was fitted using the method of least squares.

values in Table 1, there is still a large scatter among these figures. This range of values must be attributable to some other influence. For two sites, two different carbonate-free 


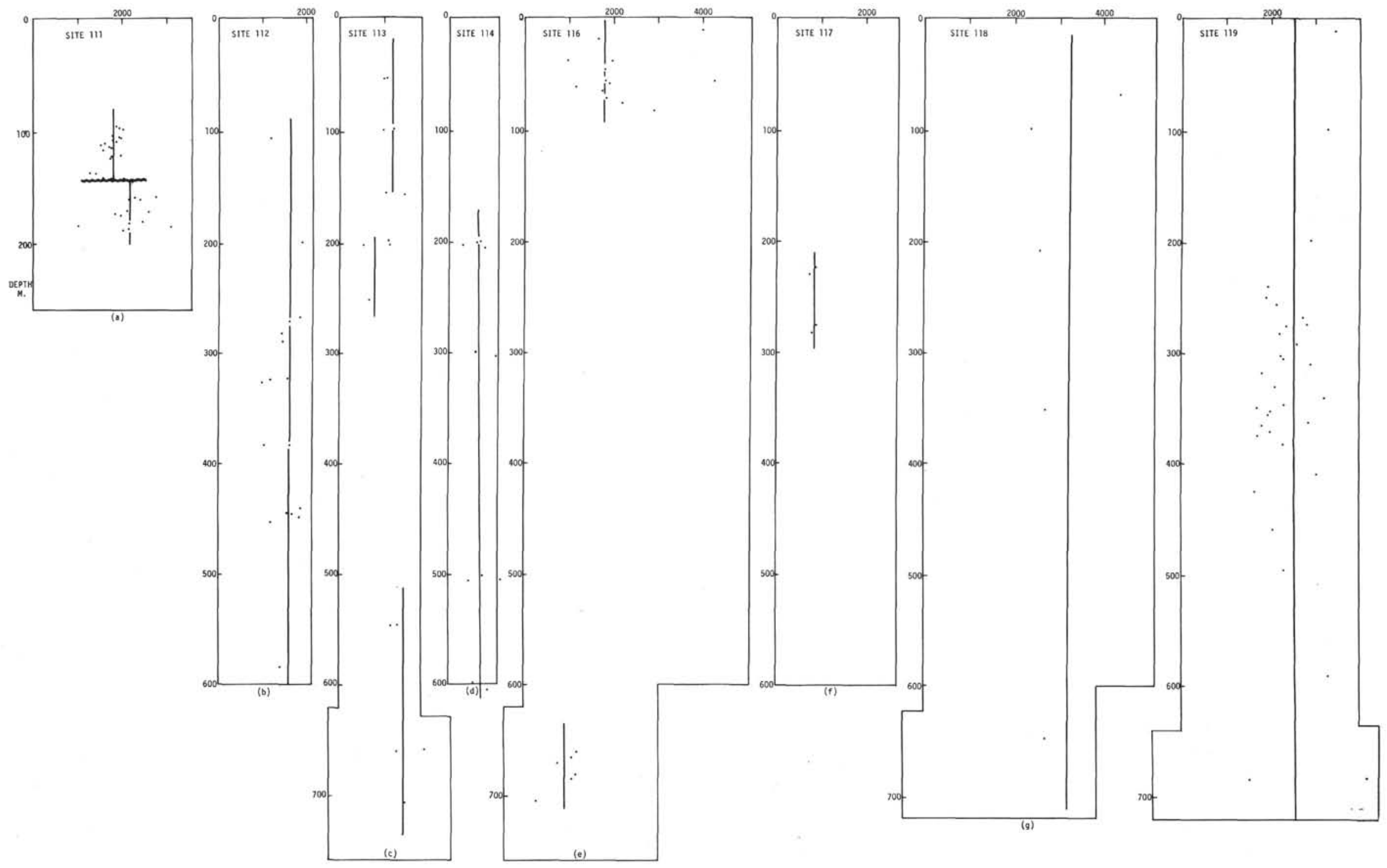

Figure 5. Plots of natural gamma counts, calculated on a carbonate-free basis, against depth down each site. Trend lines have been drawn through the data. In Figure 5e points derived from samples with more than $90 \%$ carbonate have been omitted (see text). 
TABLE 1

Best Estimate of Carbonate-free, Silica-free Counts for Each Site

\begin{tabular}{|c|c|c|}
\hline Site & Counts & Comments \\
\hline 111 & 2000 & \\
\hline 112 & 6000 & \\
\hline 113 & 1200,1600 & $\begin{array}{l}1200 \text { applies to clay and marl with } \\
\text { strong terrigenous influence (Cores } \\
1-3 \text { ), } 1600 \text { applies to dark laminated } \\
\text { mudstones and mudflow breccia } \\
(\text { Cores } 7-9 \text { ). }\end{array}$ \\
\hline 114 & 700 & $\begin{array}{l}\text { No allowance made for high organic } \\
\text { silica content. }\end{array}$ \\
\hline 116 & 1800,900 & $\begin{array}{l}1800 \text { applies to glacial ooze, } 900 \\
\text { applies to ooze with chalk; values cal- } \\
\text { culated from carbonate contents over } \\
90 \% \text { omitted; see text. }\end{array}$ \\
\hline 117 & $\begin{array}{r}3450 \\
900\end{array}$ & $\begin{array}{l}\text { Based on } 1 \text { point only from Hole } 117 \text {. } \\
\text { Based on } 4 \text { points from Hole } 117 \mathrm{~A} \text {. }\end{array}$ \\
\hline 118 & 3250 & \\
\hline 119 & 2500 & \\
\hline
\end{tabular}

gamma activities were obtained. At Site 113 the lower value comes from gray-colored cores with a strong terrigenous influence, while the higher value comes from dark rocks apparently lacking a terrigenous influence.

At Site 116 dark sediments are unknown, but the higher count was obtained from the glacial sediments which are known to possess a relatively high content of detrital minerals (see Chapter 13). Thus, these two sites illustrate the two basic sources of radioactivity in deep-sea sediment, namely (i) absorbed uranium, thorium and potassium usually associated with dark rocks and (ii) detrital minerals. An attempt to explain the variation seen in Table 1 in terms of these two factors will be made here.

Table 2 lists the occurrence of dark sediments and/or a terrigenous influence at the points from which the carbonate samples, used to obtain the gamma values in Table 1, came. From Table 2 it is apparent that many of the higher counts in Table 1 are due to a terrigenous influence, although the degree of this influence is hard to establish without detailed microscope examination of the carbonate samples. The common occurrence of dark rocks at a site is no certain indication of high gamma counts, as can be seen by comparing the figures for Sites 113 and 114 . The relatively low count of Site 114 (and perhaps that of Hole $117 \mathrm{~A}$, also) may be a result of simply a lack of supply of radioactive minerals, especially micas, whereas, the high count of Site 113 may be associated with the proximity of Greenland to this site.

As far as can be determined from the available data, sedimentation rate has no influence on the natural gamma activity within a given site. Such a relationship was expected qualitatively on the basis that a slower sedimentation rate will lead to greater absorption of uranium,
TABLE 2

Relationship of Gamma Counts in Table 1 to Dark Sediment and/or Terrigenous Influence

\begin{tabular}{|c|c|c|}
\hline Site & Dark Sediments & Terrigenous Influence \\
\hline 111 & Occasional & $\begin{array}{l}\text { Glacial, pre-Maestrichtian } \\
\text { cores }\end{array}$ \\
\hline 112 & Rare & $\begin{array}{l}\text { Common (?) since has } \\
\text { nannofossil marl and clays }\end{array}$ \\
\hline 113 & $\begin{array}{l}\text { Common for cores } \\
\text { giving } 1600 \text { counts }\end{array}$ & $\begin{array}{l}\text { Strong for cores giving } \\
1200 \text { counts }\end{array}$ \\
\hline 114 & Common & Absent \\
\hline 116 & Absent & $\begin{array}{l}\text { Glacial cores only ( } 1800 \\
\text { counts) }\end{array}$ \\
\hline 117 & Occasional & Absent \\
\hline 118 & Rare & $\begin{array}{l}\text { Cores at } 100,200 \text { meters } \\
\text { have sands; rest are clays }\end{array}$ \\
\hline 119 & $\begin{array}{l}\text { Very rare above } \\
360 \text { meters, occa- } \\
\text { sional below } 360 \\
\text { meters }\end{array}$ & $\begin{array}{l}\text { Throughout (?) since has } \\
\text { low carbonate nannofossil } \\
\text { clays }\end{array}$ \\
\hline
\end{tabular}

thorium and potassium by clays. It may be however that sedimentation rates in the deep-sea are at any rate so slow that available sites for uranium, thorium and potassium ions are always filled. Alternatively, Russell (1945) has argued that the chemical environment of deposition may influence the radioactivity much more than the sedimentation rate, or that the rate of supply of radioactive material relative to the sedimentation rate is the deciding factor.

\section{GAMMA - DENSITY PLOTS}

For each main lithologic type at each site the ranges of the gamma counts (adjusted to 60 per cent porosity) and G.R.A.P.E. density were expressed on a plot by rectangles with sides corresponding to the limits of each range. It was hoped that different lithologies would occupy different parts of such plots.

The first plot (Figure 6) contains data from PliocenePleistocene glacial sediments and from all the basalts. The boxes which include turbidites have dashed sides and have the highest density sediments. On the whole the other glacial sediments have densities in the range 1.45 to 1.7 $\mathrm{gm} / \mathrm{cc}$. Figure 6 also shows up the fact that the glacial sediments of sites to which bottom transported and/or ice-rafted sediments from the continents had easy access have the highest gamma counts. The basalts have densities around $2.6 \mathrm{gm} / \mathrm{cc}$.

Figure 7 contains data from pre-glacial sediments. The pattern here is confused and it is not possible to detect an increase of sediment density with age although, as expected, all the highly calcareous sediments are found in the region of low gamma counts. Many sediments exhibit a wide range of both density and gamma counts, and this indicates that a plot based on just a simple classification of sediment types cannot show up the variety of parameters 


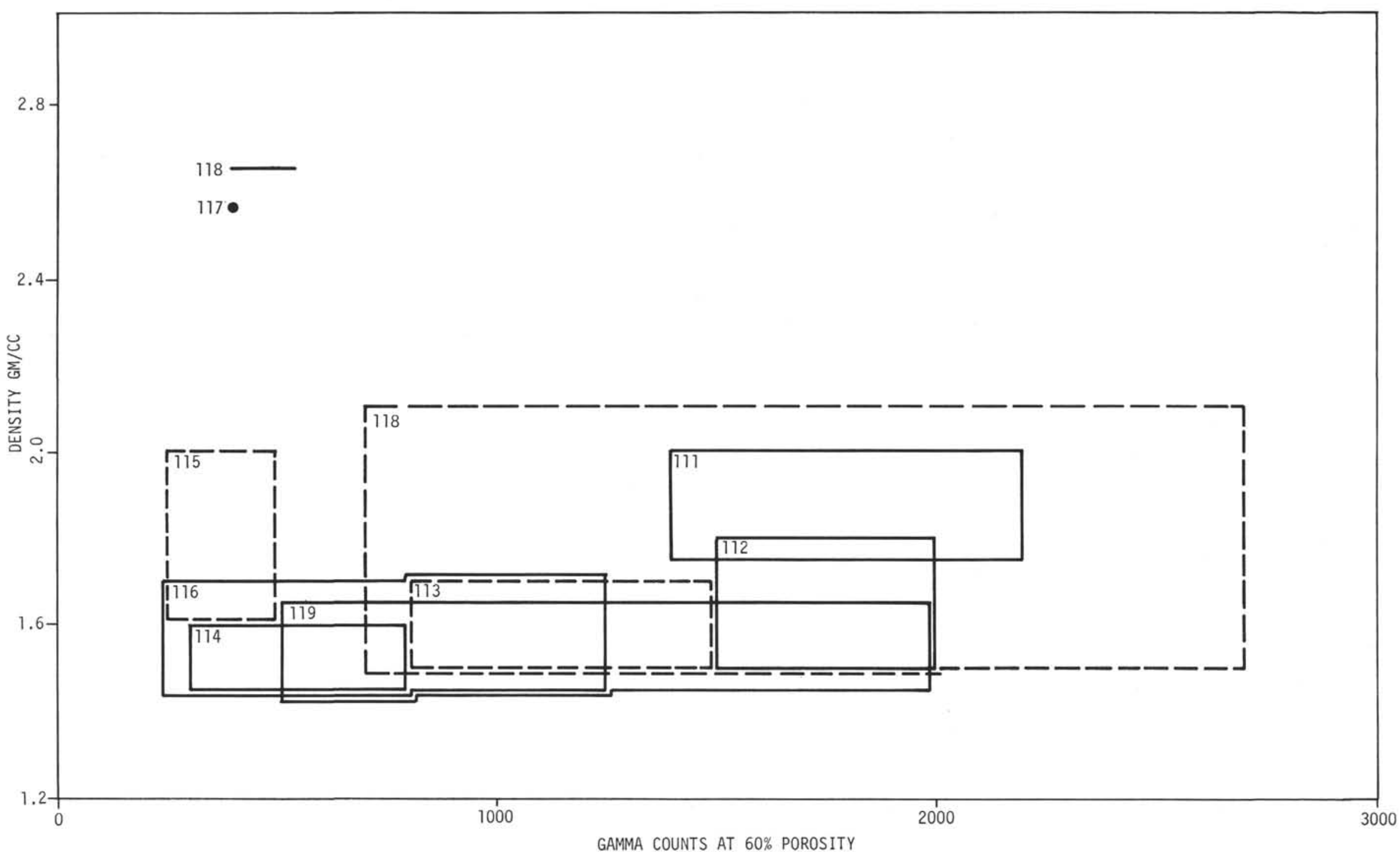

Figure 6. Plot of density versus gamma counts (adjusted to $60 \%$ porosity) for glacial sediments and basalts. The boxes enclose the range of values for each site. Site numbers are written in the top left corners of boxes. Dashed sides to boxes indicate that turbidites are included. 


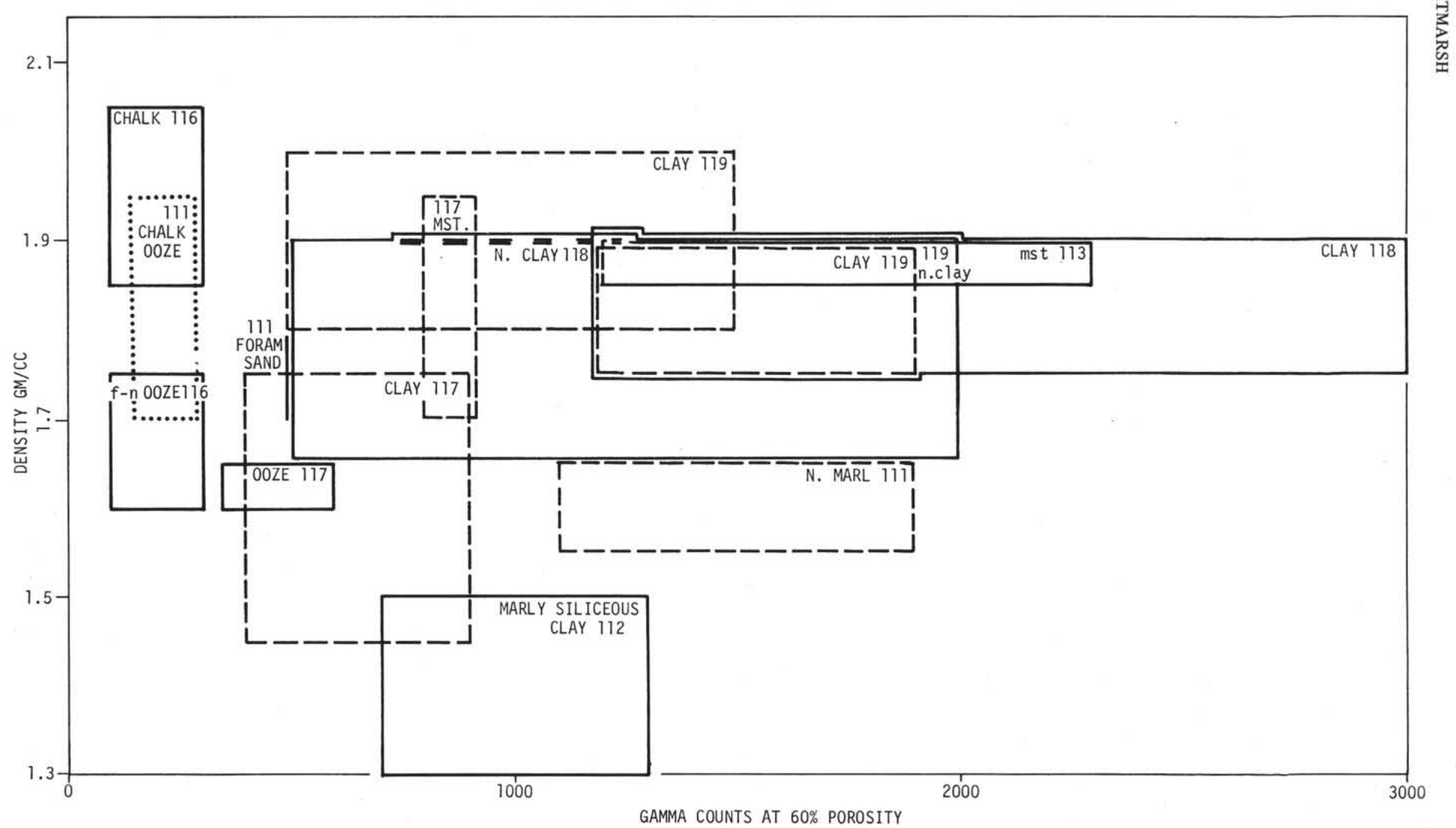

Figure 7. Plot of density versus gamma counts (adjusted to $60 \%$ porosity) for main types of preglacial sediment. Each box has dimensions corresponding to the range of observed values for each main sediment type. The site and lithology are given in the top right of each box ( $f=$ foraminiferal, $n=n a n n o f o s s i l$, mst $=$ mudstone). The box margin indicates the sediment age: Pliocene to Oligocene, _- Eocene, Paleocene, ......... Cretaceous. 
which causes the complex density and gamma variations observed in practice.

\section{SEDIMENT DENSITY AND DOWNHOLE DEPTH}

Sediment density depends on basic properties of a sediment, such as grain-size distribution, grain density and the degree of lithification. In addition, laboratory experiments show that unconsolidated sediments increase in density under uniaxial stress (for example, Laughton, 1957). Therefore, we may expect to find some correlation between sediment density and depth below the seabed, which is directly related to overburden pressure.

To investigate the depth dependence of sediment density measured on Leg 12 cores, the mean G.R.A.P.E. density of each full section of core which did not include watery sediment was plotted for each site. Data of Site 115 were omitted because of their limited depth distribution. Densities were chosen from those shorter lengths of core which were not unsuitable, where suitable whole core sections did not exist, if a gap in the depth distribution of data would have otherwise resulted.

No simple increase of density with depth occurs at Site 111 (Figure 8a), the minimum around 160 meters being caused by foraminiferal ooze and nannoplankton marls. At Site 112 (Figure 8b), the relatively low densities between 200 and 400 meters are due to silt and clay rich in nannofossils, Radiolaria and diatoms. Very broadly the sediments at Site 113 (Figure $8 \mathrm{c}$ ) do increase in density downwards, while at Site 114 (Figure 8d) there is no suggestion of such a trend. After a relatively rapid increase in density in the first 80 meters of Site 116 (Figure 8e), a gradual increase of density with depth is apparent. At Site 117 (Figure 8f), a peak in the plot is caused by dense mudstones. At Site 118 (Figure 8g), density increases down to 500 meters, but then decreases due to some Miocene clays and silts. Density only increases in the upper 300 meters of Site 119 (Figure 8h) and then remains constant.

It is clear from Figure 8 that density does not normally increase steadily with depth in the North Atlantic. Variations in sediment type seem to be more important than overburden pressure in causing changes of density with depth. Overburden pressure in fact increases only slowly with depth reaching about $49 \mathrm{~kg} / \mathrm{cm}^{2}$ at 700 meters. Laughton's (1957) experimental results showed that the density of a foraminiferal ooze increased by between 0.2 and $0.3 \mathrm{gm} / \mathrm{cc}$ under this pressure. Where the lithology is fairly uniform, however, as at Site 116 and in the top 350 meters of Site 119, density does increase uniformly with depth at a rate comparable to that determined by Laughton.

\section{SEDIMENT VELOCITY: IN SITU VALUES AND COMPARISON WITH OTHER DATA}

The laboratory measurements of compressional wave velocity will not represent the true in situ values because of the removal of overburden pressure and the changes in temperature and hydrostatic pressure. Without carrying out compaction experiments on the cores, it is not possible to gauge precisely the correction to be applied to the laboratory measurements to obtain in situ values.
However, it is possible to obtain a good estimate of the in situ mean velocity between the sea bed and those reflectors observed on the profiler records which can be identified during drilling by drilling characteristics or by measured changes in acoustic impedance. The amount of the correction can be assessed by calculating mean velocities from the laboratory measurements, provided these are well distributed dov $\mathrm{n}$ a hole, and comparing the mean velocity/depth curve so obtained with the points derived from actual downhole identification of reflectors. Finally, a corrected curve for each site is obtained by constraining the calculated curve to pass through the derived points by adding a linear depth dependent factor to it. These curves can then be converted to depth/time curves, which are of direct use in interpreting seismic profiling records (Figure 9), and to mean velocity/time curves for comparison with other data (Figure 10).

Figure 9 illustrates the two-way travel time/depth curve for each site and indicates the errors in depth determination to be expected if the commonly assumed velocity of 2.0 $\mathrm{kms} / \mathrm{sec}$ is employed. Figure 10 was drawn for comparison of mean velocity/travel time curves for each site with data obtained with sonobuoys. The curves of Houtz et al. (1968) were derived from observations over unconsolidated sediments in the Gulf of Mexico and the northwest and east Atlantic. These authors point out that the velocities in the north Atlantic, where sediment deposition by nepheloid currents is believed to be important, are less than those found in areas where turbidity current deposits contribute substantially to the sediments, although the precise reason for this velocity difference is not clear. However most of the data presented here, especially the curves from Sites 112,114 and 119 , have generally significantly lower velocities at a given depth than even the Atlantic curve of Houtzet al. Part of the discrepancy may lie in the distributions of sonobuoy stations and drilling sites, and there are numerous factors which could contribute to give different mean velocity curves. The curves derived from identifying reflectors in the drill holes will also depend on the distribution and representativeness of velocity measurements down each hole. Poor measurements near the top of a hole can bias the mean velocities to much deeper horizons.

Sites 111 and 117 have higher velocities than the other Leg 12 sites because in both cases Eocene sediments were sampled close to the sea bed. Sites 118 and 119 were both situated in the Bay of Biscay in depths exceeding 4500 meters. The sequence at Site 118 was predominantly turbidites, while the upper 350 meters ( 0.22 seconds) at Site 119 were pelagic in origin. The difference between the velocity curves of these two sites can probably be attributed to this difference in lithology. In contrast with the upper sequence of Site 119, Site 116-which also contains a turbidite-free sequence-has a consistently higher mean velocity. The sequence at Site 116 was deposited in depths less than 1200 meters and at an average rate $(3.6 \mathrm{~cm} / 1000$ yrs) generally several times those calculated at various depths at Site 119. The sequence at Site 114, however, is much poorer in calcium carbonate (average 15 per cent) and was deposited about three times faster than the sequence at Site 116. Site 114 exhibits the lowest mean 


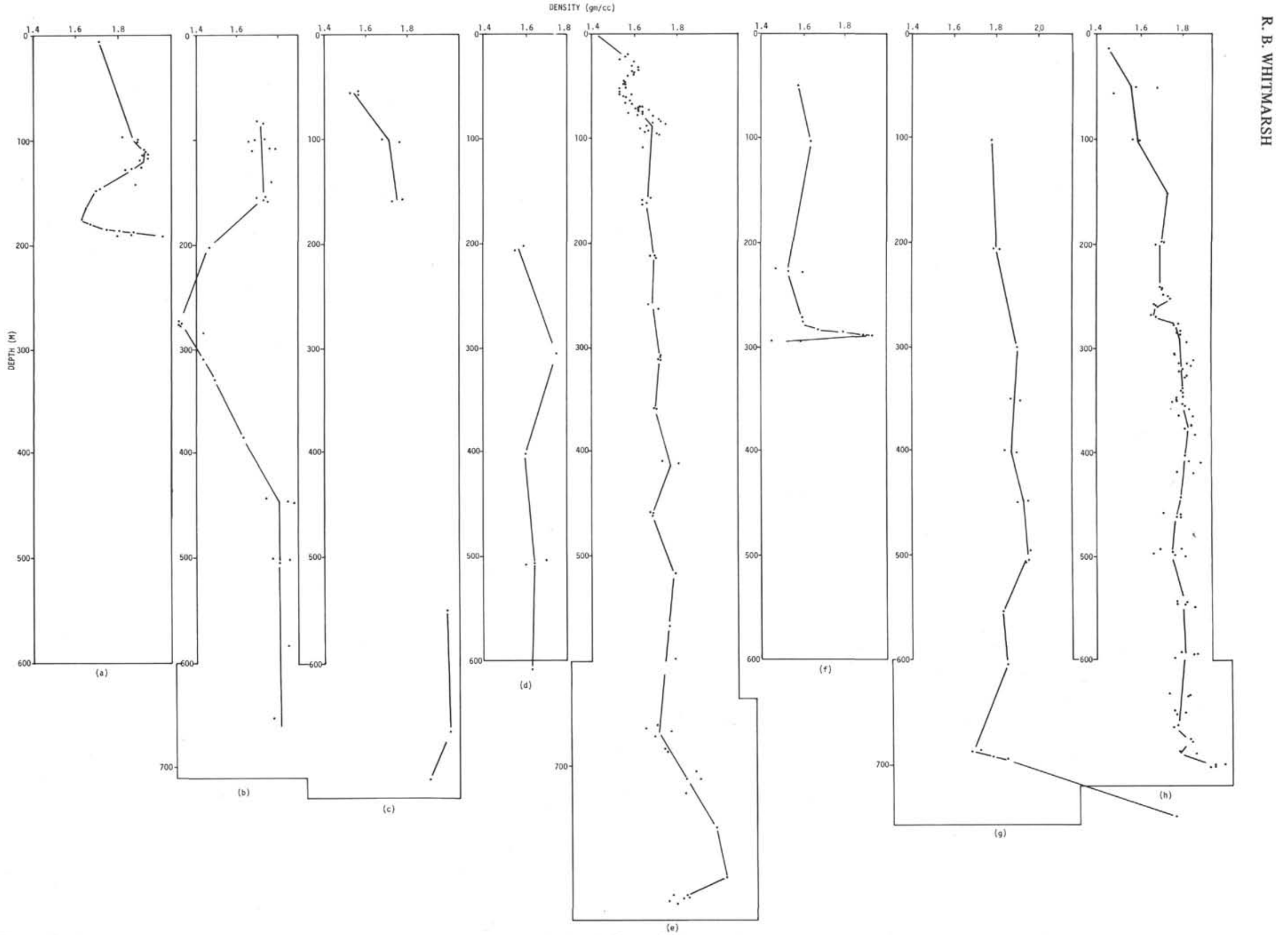

Figure 8. Mean sediment density of core sections plotted against downhole depth for each site. 


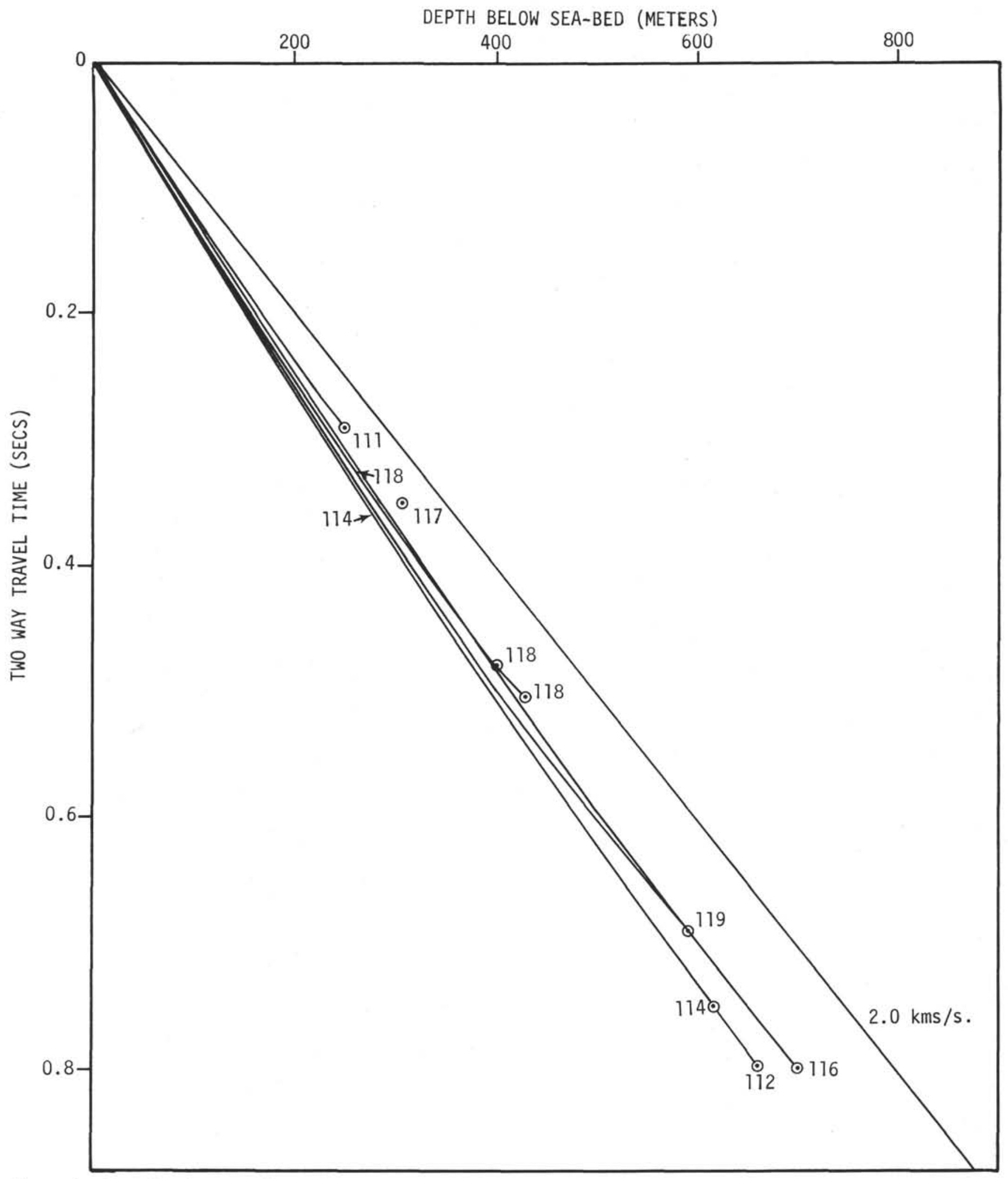

Figure 9. Time/depth curves for each site calculated from the shipboard velocity measurements and constrained to pass through points $\bigcirc$ representing reflecting horizons identified during drilling (see text). A line representing a constant velocity of $2.0 \mathrm{kms} / \mathrm{sec}$ is drawn for comparison. 


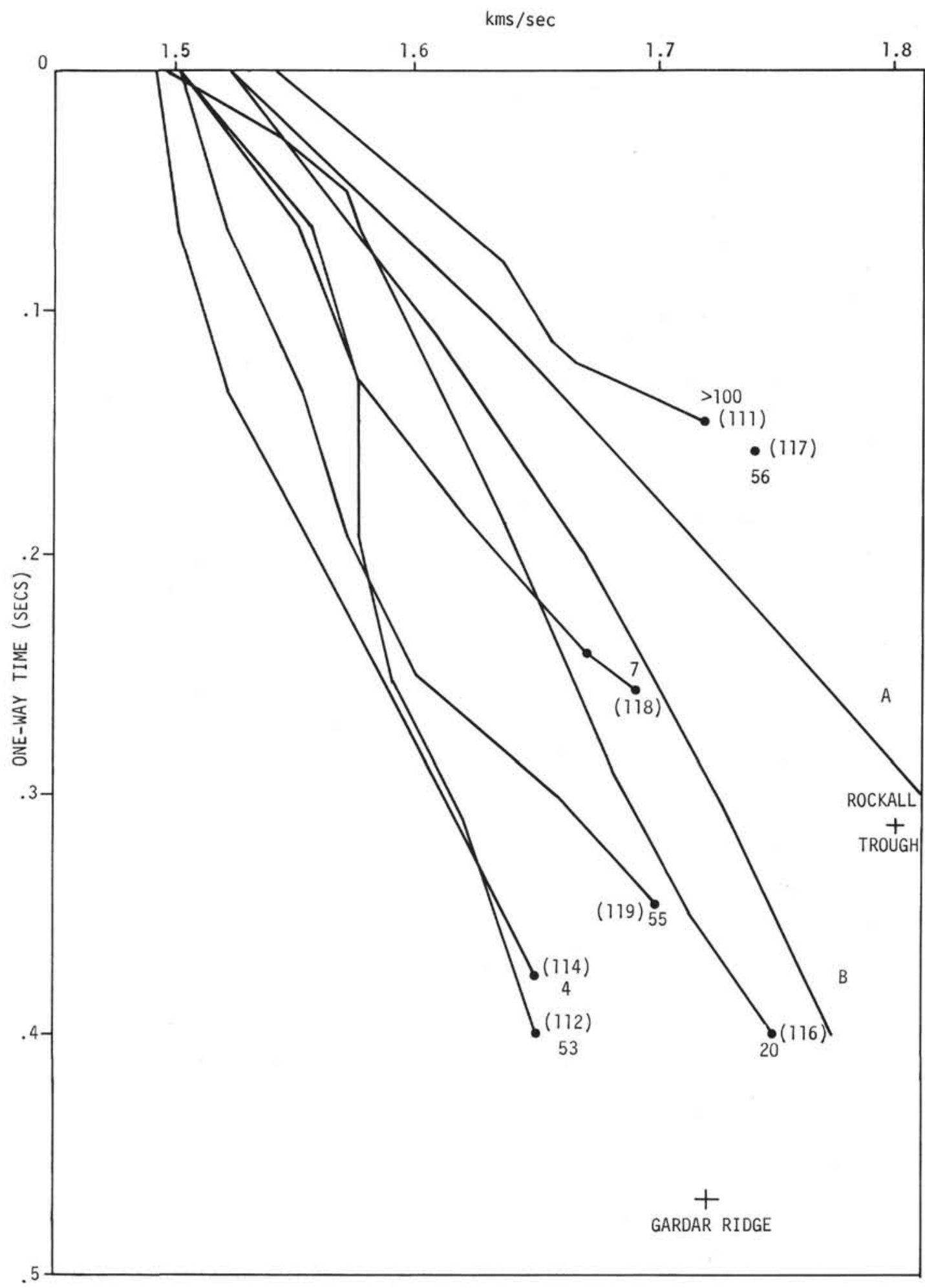

Figure 10. Velocity/time curves for each site (with site numbers in brackets) derived from the data in Figure 8. The points 0 correspond to reflectors identified during drilling and their age in $10^{6}$ years is also given. The two bold lines $A$ and $B$ are the mean curves for the Gulf of Mexico and the Atlantic, respectively, obtained by Houtz et al. (1968) from sonobuoy data (their figures 14 and 18). The crosses correspond to data obtained from sonobuoys (Rockall Trough, personal communication, J. Si buet; Gardar Ridge, Station R77, personal communication, J. Ewing). 


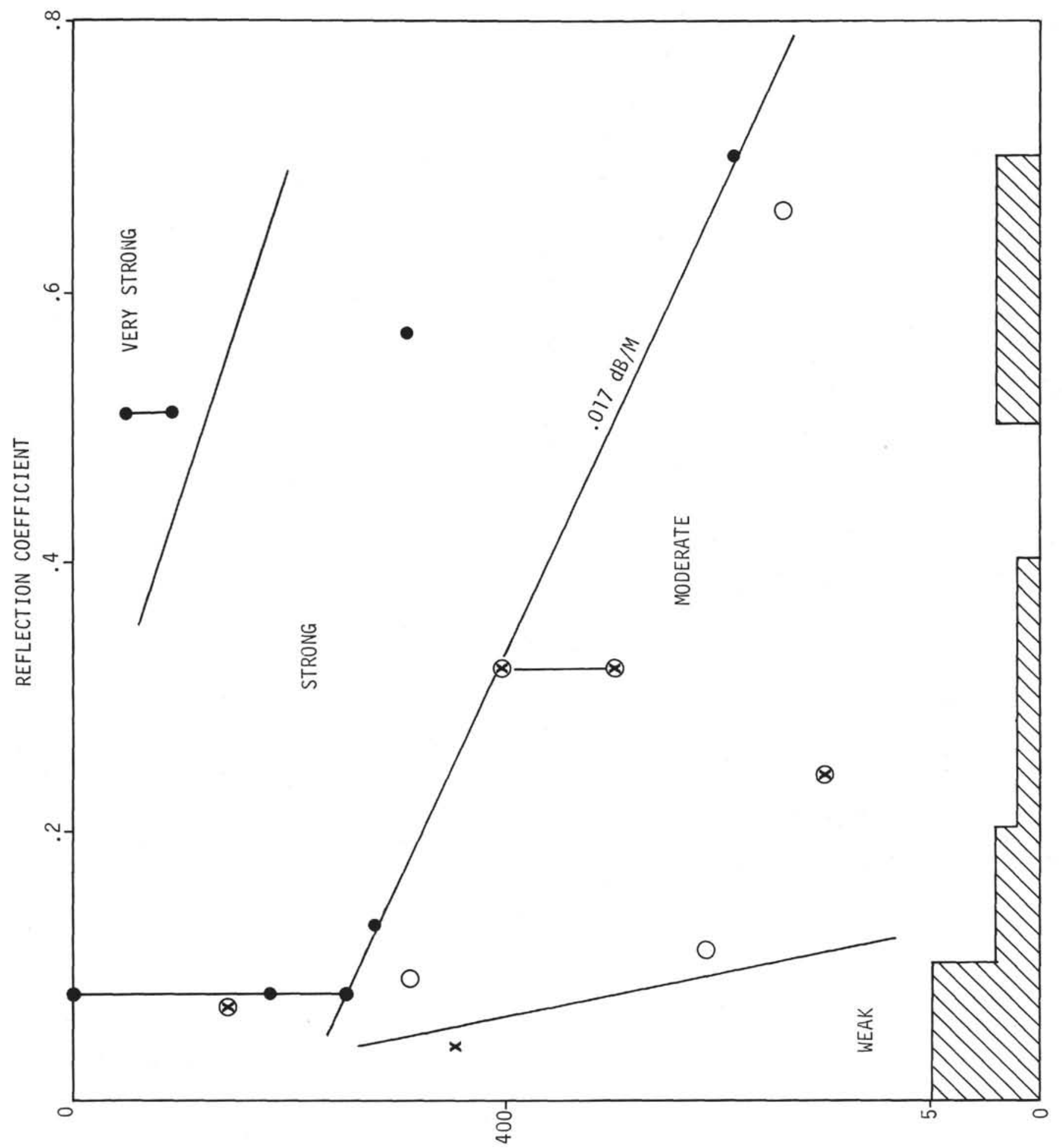

(W) $\mathrm{H} \perp \mathrm{d} \exists \mathrm{O}$

Figure 11. Reflection coefficients from Table 3 plotted against depth. The symbols denote the qualitative strength of reflections, - strong, o moderate, $x$ weak, and the plot has been divided into fields of equal reflection strength. The histogram at the bottom of the figure gives the distribution of calculated reflection coefficients. 
TABLE 3

Properties of Reflectors Encountered on Leg XII

\begin{tabular}{|c|c|c|c|c|c|c|c|c|c|c|}
\hline \multirow[b]{2}{*}{ Site } & \multirow{2}{*}{$\begin{array}{l}\text { Two-way } \\
\text { Time } \\
\text { (secs) }\end{array}$} & \multirow{2}{*}{$\begin{array}{l}\text { Type of } \\
\text { Reflection }\end{array}$} & \multirow{2}{*}{$\begin{array}{l}\text { Cause of } \\
\text { Reflection }\end{array}$} & \multicolumn{2}{|c|}{$\begin{array}{l}\text { Velocity } \\
(\mathrm{kms} / \mathrm{sec})\end{array}$} & \multicolumn{2}{|c|}{$\begin{array}{l}\text { Density } \\
(\mathrm{gm} / \mathrm{cc})\end{array}$} & \multirow{2}{*}{$\begin{array}{l}\text { Reflection } \\
\text { Coefficient }\end{array}$} & \multirow{2}{*}{$\begin{array}{l}\text { Depth } \\
(\mathrm{m})\end{array}$} & \multirow[b]{2}{*}{ Remarks } \\
\hline & & & & Above & Below & Above & Below & & & \\
\hline 111 & 0.18 & Weak, discontinuous & Clay to sand & 1.66 & 1.59 & 1.89 & 1.72 & -0.07 & 143 & \\
\hline 111 & 0.21 & Strong & Chalk & 1.60 & 1.75 & 1.75 & 1.88 & +0.08 & 185 & \\
\hline 111 & 0.29 & $\begin{array}{l}\text { Weak, intersection } \\
\text { of dipping and } \\
\text { subhorizontal beds }\end{array}$ & Sandstone & - & - & - & - & - & 250 & \\
\hline 112 & 0.41 & $\begin{array}{l}\text { Weak to strong, } \\
\text { discontinuous }\end{array}$ & $\begin{array}{l}\text { Positive density } \\
\text { gradient, drilling } \\
\text { discontinuity }\end{array}$ & 1.55 & 1.60 & 1.41 & 1.63 & +0.09 & ca. 315 & $\begin{array}{l}\text { Parameters chosen from Cores } 9 \\
\text { and } 12,75 \text { meters apart. }\end{array}$ \\
\hline 112 & $0.75,0.80$ & $\begin{array}{l}\text { Weak to strong } \\
\text { diffuse hyperbolae }\end{array}$ & Basalt & $1.66^{x}$ & $5.00^{x}$ & 1.77 & $2.60^{x}$ & +0.63 & 660 & $\begin{array}{l}\text { Basalt parameters assumed, "above" } \\
\text { velocity from Core } 14 .\end{array}$ \\
\hline 114 & 0.75 & $\begin{array}{l}\text { Strong diffuse } \\
\text { hyperbolae }\end{array}$ & Basalt & 1.67 & 5.89 & 1.63 & $2.60^{x}$ & +0.70 & 618 & Basalt density assumed. \\
\hline 115 & $0.06,0.11$ & Very strong & $\begin{array}{l}\text { Volcanogenic } \\
\text { sandstones }\end{array}$ & $1.55^{\mathrm{x}}$ & 3.70 & $1.40^{\mathrm{x}}$ & 1.80 & +0.51 & 50,90 & "Above" parameters assumed. \\
\hline 116 & 0.80 & $\begin{array}{l}\text { Moderate to weak } \\
\text { diffuse discontin- } \\
\text { uous }\end{array}$ & $\begin{array}{l}\text { Increasing propor- } \\
\text { tion of chalk }\end{array}$ & $1.61^{\mathrm{x}}$ & 2.17 & 1.80 & 2.10 & +0.22 & ca. 700 & $\begin{array}{l}\text { Parameters chosen from Cores } 19 \\
\text { and } 25,110 \text { meters apart. }\end{array}$ \\
\hline 117 & $0.04-0.16$ & $\begin{array}{l}\text { Strong diffuse } \\
\text { discontinuous }\end{array}$ & $\begin{array}{l}\text { Stringers of } \\
\text { cherty limestone }\end{array}$ & - & - & - & - & - & $20-150$ & \\
\hline \multirow[t]{2}{*}{117} & 0.32 & $\begin{array}{l}\text { Strong } \\
\text { double } \\
\text { reflector }\end{array}$ & $\begin{array}{l}\text { Mudstone and } \\
\text { hard clay }\end{array}$ & 1.61 & 1.75 & 1.60 & 1.90 & +0.13 & 280 & \\
\hline & 0.35 & & $\begin{array}{l}\text { Basalt, sandstone, } \\
\text { conglomerate }\end{array}$ & 1.75 & 4.80 & 1.90 & 2.56 & +0.57 & 310 & \\
\hline 118 & $0.00-0.30$ & Many strong echoes & Turbidites & 1.50 & 1.50 & 1.70 & 2.00 & \pm 0.08 & $0-250$ & $\begin{array}{l}\text { Sign of reflection coefficient } \\
\text { depends on where reflection occurs } \\
\text { in sequence of graded beds. } \\
\text { Density values are typical for } \\
\text { Cores } 1 \text { to } 3 \text {. }\end{array}$ \\
\hline 118 & $0.48-0.51$ & $\begin{array}{l}\text { Moderate to weak } \\
\text { double reflector }\end{array}$ & $\begin{array}{l}\text { Sandstones, hard } \\
\text { layers met in } \\
\text { drilling }\end{array}$ & 1.56 & 3.00 & 1.95 & 1.95 & +0.32 & $400-505$ & \\
\hline 119 & 0.45 & Weak discontinuous & $\begin{array}{l}\text { Velocity decrease in } \\
\text { nannofossil clay } \\
\text { above unconformity }\end{array}$ & 1.66 & 1.58 & 1.85 & 1.80 & -0.04 & 355 & \\
\hline 119 & 0.69 & Moderate diffuse & $\begin{array}{l}\text { Hard drilling, } \\
\text { calcarenite bed }\end{array}$ & 2.06 & 2.66 & 1.85 & 1.80 & +0.11 & 590 & $\begin{array}{l}\text { "Below" density may be low due } \\
\text { to opaline silica. }\end{array}$ \\
\hline
\end{tabular}

$\mathrm{x}=$ Assumed Value 
velocities of the entire leg. Clearly from the above discussion, factors such as age, sediment type, and rate and of deposition have affected the mean sediment velocities.

For the Leg 12 holes on average, the corrected and uncorrected mean velocity curves differ by $(0.10 \pm 0.03)$ $\mathrm{km} / \mathrm{sec}$ at a depth of 500 meters. Hence, the laboratory velocity and true instantaneous velocity at this depth, where the effective overburden pressure is around 26 $\mathrm{kg} / \mathrm{cm}^{2}$, will differ by around $0.20 \mathrm{~km} / \mathrm{sec}$. This difference is similar to that obtained by artificially compacting surficial sediments to the same pressure (Laughton, 1957).

\section{THE NATURE OF SOME REFLECTORS}

As shown in the chapter concerned with each site, it has been possible to identify some of the reflections seen on the records obtained with a 20 cubic-inch air-gun (sometimes supplemented by a 5 cubic-inch air-gun) with changes of lithology and physical properties detected by coring and/or drilling. These reflections are studied in greater detail here, and the likely reflection coefficients (R) at vertical incidence are calculated for the reflectors using the formula for plane waves:

$$
\mathrm{R}=\frac{\rho_{2} \mathrm{c}_{2}-\rho_{1} \mathrm{c}_{1}}{\rho_{2} \mathrm{c}_{2}+\rho_{1} \mathrm{c}_{1}}
$$

where

\section{$\rho$ denotes density}

c denotes compressional wave velocity

the subscripts 1, 2 refer to the upper, lower medium, respectively

The reflections are listed in Table 3 . The strengths of the reflections are gauged qualitatively relative to the bottom echo so that the effects of system gain and transmission through the sea are avoided. A "strong" echo is one of comparable strength to the bottom reflection. A diffuse reflection is one which lasts for a considerably longer period than the bottom echo. Where a reflection is apparently caused by a gradual change in impedance, density and velocity values have been chosen from depths some tens of meters apart (see column headed Remarks, Table 3). Normally however values have been taken from adjacent cores.

Two reflectors with the same reflection coefficient but at different depths will give different amplitude reflections; the deeper reflector will give the weaker reflection, and vice versa, due to sound attenuation within the sediments. This relationship is exhibited in Figure 11 with the data of Table 3. Clearly the limits of the fields drawn on this figure are a function of the profiling system used on board Glomar Challenger, but the same sort of pattern of fields should always be observed with a different system. The figure illustrates for instance that strong reflections are only rarely to be expected from reflectors deeper than 300 meters, and that any reflectors below about 1000 meters will usually only give weak reflections. It should also be noted that a crude estimate of sound attenuation in sediment can be made from Figure 11. The slope of the line separating the strong and moderate fields corresponds to an amplitude loss of $0.017 \mathrm{~dB} / \mathrm{m}$. This figure is comparable to $0.009 \mathrm{~dB} / \mathrm{m}$ obtained by Stoll and Bryan (1970) for sediment at $100 \mathrm{~Hz}$ during a theoretical treatment of sound attenuation in saturated sediments.

It is usually assumed that reflections arise from changes in sediment velocity alone. An inspection of Table 3 reveals however that in some instances density changes appear to be the major, or even the sole, cause of a reflector. Examples are the 0.18 second reflector at Site 111, the 0.41 second reflector at Site 112 , the 0.32 second reflector at Site 117, and the turbidite reflections at Site 118. Therefore, it is clearly not essential, nor necessarily correct, when interpreting seismic refraction or variable angle reflection data to identify each reflector with a discontinuity in velocity, although when velocities are averaged between reflectors such discontinuities appear to exist.

\section{REFERENCES}

Barsukov, O. A., Blinova, N. M., Vybornykh, S. F., Gulin, Yu. A., Dakhnov, V. N., Larionov, V. V. and Kholin, A. I., 1964. Radioactive Investigations of Oil and Gas Wells. Translated by J. O. H. Muhlhaus; N. Rast. (Ed.). London (Pergamon Press).

Beers, R. F., 1945. Radioactivity and organic content of some Paleozoic shales. Bull. Am. Assoc. Petrol. Geologists. 29 (1), 1.

Houtz, R., Ewing, J. and LePichon, X., 1968. Velocity of deep-sea sediments from sonobuoy data. J. Geophys. Res. 73, 2615.

Hülsemann, J., 1966. On the routine analysis of carbonates in unconsolidated sediments. J. Sediment Petrol. 36, 622 .

Laughton, A. S., 1957. Sound propagation in compacted ocean sediments. Geophysics. 22 (2), 233.

Russell, W. L., 1945. Relation of radioactivity, organic content and sedimentation. Bull. Am. Assoc. Petrol. Geologists. 29 (10), 1470.

Stoll, R. D. and Bryan, G. M., 1970. Wave attenuation in saturated sediments. J. A coust. Soc. Am. 47, 1440.

Turekian, K. T. and Bertine, K. K., 1971. Deposition of molybdenum and uranium along the major ocean ridge systems, Nature 229, 250. 